\title{
Editorial team and Arnold Berliner Award 2019
}

\section{Matthias Waltert ${ }^{1}$}

Published online: 14 August 2019

(C) Springer-Verlag GmbH Germany, part of Springer Nature 2019

Assisted by its board of editors, this issue of The Science of Nature - Naturwissenschaften has been handled by a new editorial team. The new team includes Matthias Waltert, the new Editor-in-Chief, and Ms. Paula Roig Boixeda, the new Managing Editor, and is based at the University of Goettingen in Germany. The former team, Sven Thatje and Rumyana Jeleva, has served the journal for many years and phased out its work over the past months. Sven Thatje owns a very special place in the journal's history, not only because he completed ten years as Editor-in-Chief but also because he transformed a journal of the German-speaking community into one that is recognised by international bibliographical databases (Thatje 2015). On behalf of all the members of the editorial board, I thank Sven Thatje for his commitment in the past and his continuing advice regarding matters of editorship. I am also grateful to Lars Koerner for his confidence in handing over the responsibility of managing The Science of Nature to us and for helping to bridge the gap between the old and new editorial teams.

The Science of Nature will continue to 'inform all those working in scientific fields, either researchers or teachers, about what interested them outside their own fields' as stated by Arnold Berliner, the founder of Naturwissenschaften, in 1913 (Autrum 1988). Maintaining a platform that does not only address the own scientific peers is undoubtedly a difficult task, and it can only be successful with the support of an active team of editors who share this vision and jointly represent the breadth of all major scientific fields. Currently, the editorial board consists of a diverse group of scientists with backgrounds in the organismic biological sciences. Their expertise encompasses organic chemistry, geology, palaeontology, evolution, behaviour, morphology, physiology, and genetics as

Matthias Waltert mwalter@gwdg.de

1 Conservation Biology/Workgroup on Endangered Species, Faculty of Biology and Psychology, University of Göttingen, Bürgerstrasse 50, 37073 Göttingen, Germany well as biogeography, ecology, and conservation. From a taxonomic point of view, most of the editors work with animals, but others have experience working with plants, fungi, and microbes. The editors hold positions at universities, are curators of museums or work at independent research institutions, and come from Europe, the Middle East, North America, and Australia. My sincere thanks go to all of them for their continuous support.

Finally, I am pleased to announce the winner of the 2019 Arnold Berliner Award. Since 2012, The Science of Nature grants the Arnold Berliner Award to the lead authors of articles distinguished by their excellent, original, and-especially-interdisciplinary research. As such, the awarded articles ideally reflect the vision of Arnold Berliner (Autrum 1988; Thatje 2018). The award is sponsored by Springer and includes the Arnold Berliner Award medal (Fig. 1), a biennial subscription to the

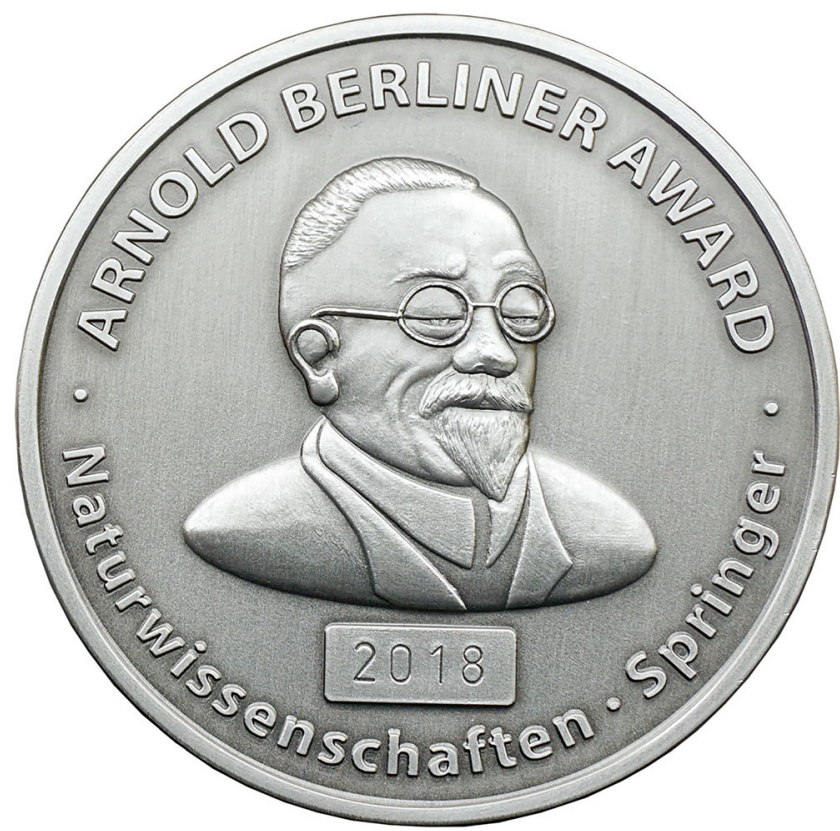

Fig. 1 The Arnold Berliner Award medal. Arnold Berliner (1862-1942) was the founding editor of The Science of Nature (formerly Naturwissenschaften) and the journal's editor in chief from 1913 to 1935 
electronic edition of The Science of Nature, a 500-Euro voucher for Springer ebooks, and a cash prize of 250 Euro. This year, the board of editors has decided to award Martin Nyffeler (Fig. 2) who, together with Can Şekercioğlu and Christopher Whelan, published the first global assessment of insect biomass consumption by birds (Nyffeler et al. 2018). Their article presents a meta-analysis of 103 studies documenting insect consumption by insectivorous birds in seven biomes. The authors estimate that birds consume between 400 and 500 million metric tons per year and conclude that

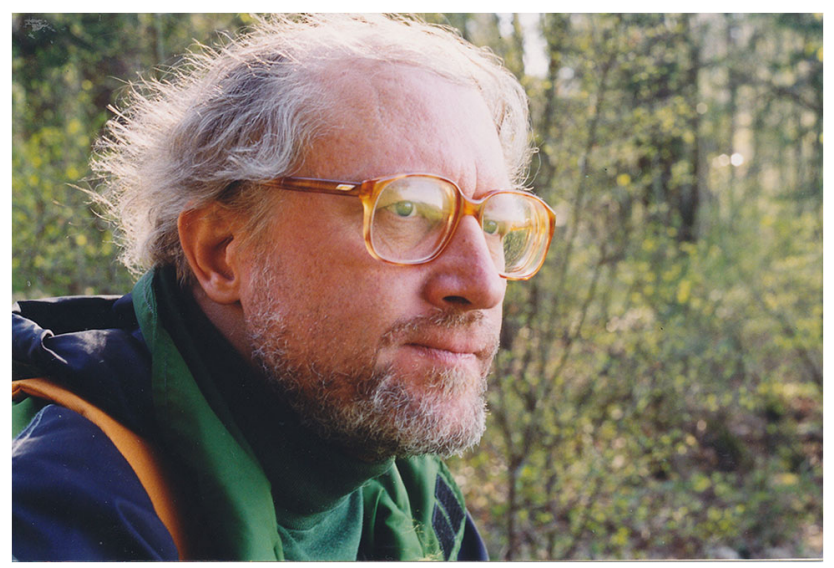

Fig. 2 PD Dr. Martin Nyffeler, winner of the 2019 Arnold Berliner Award insectivorous birds contribute to a high extent to herbivorous' insect predation, suppressing potentially harmful insect pests, especially in forest biomes. The work presented in their article lies at the interface between ornithology, ecology, and conservation, and it has broad relevance to science and management. Their study already received a considerable amount of press coverage, and it may, therefore, impact policy and conservation management. The article was published as an original research paper, but synthesises what we know about a fundamental issue and therefore represents well the scope of the journal. On behalf of the board of editors I congratulate Martin Nyffeler to the award and wish him and his colleagues all the very best success for their future research.

\section{References}

Autrum H (1988) Arnold Berliner und die "Naturwissenschaften". Naturwissenschaften 75:1-4

Nyffeler M, Șekercioğlu CH, Whelan CJ (2018) Insectivorous birds consume an estimated 400-500 million tons of prey annually. Sci Nat 105:47

Thatje S (2015) The science of nature - a new era, a new name for Naturwissenschaften. Sci Nat 102:6

Thatje S (2018) The Arnold Berliner Award 2018. Sci Nat 105:21

Publisher's note Springer Nature remains neutral with regard to jurisdictional claims in published maps and institutional affiliations. 